\title{
Serum-induced head-to-head agglutination of bovine spermatozoa
}

\author{
P. L. Senger* and R. G. Saacke \\ Department of Dairy Science, Virginia Polytechnic Institute and State University, \\ Blacksburg, Virginia 24061, U.S.A.
}

\begin{abstract}
Summary, Addition of cow serum to diluted bull spermatozoa induced marked headto-head agglutination which declined during incubation for $9 \mathrm{hr}$ at $37^{\circ} \mathrm{C}$. Maintenance of the acrosomal cap during incubation was not adversely affected by serum. Agglutinating cells were those with intact acrosomal and cell membranes, as determined by differential interference-contrast and electron microscopy. Single cells in the same treatment groups experienced more rapid acrosomal deterioration than did untreated spermatozoa. Ultrastructurally, agglutinated cells were associated by a close apposition of the cell membranes in the acrosomal region. Structural integrity of the cell membrane and acrosome of agglutinated cells was the same after $9 \mathrm{hr}$ of incubation as at the onset of the incubation period.
\end{abstract}

\section{Introduction}

The impetus for the present experiments was the work of Barros, Arrau \& Herrera (1971) in which they studied the effect of serum from females on the induction of the acrosome reaction of hamster epididymal spermatozoa. Maximal activity was found with sera obtained near the time of ovulation and minimum activity with sera from females at mid-cycle. Senger \& Saacke (1973) exposed diluted bull semen to cow serum collected at various times during the oestrous cycle and found that the acrosome reaction was not related to the stage of the cycle but that head-to-head agglutination of spermatozoa occurred as previously reported (Chang, 1947; Edwards, 1960; Padma, 1972a, b). The degree of agglutination varied markedly among serum samples, but there was an overall beneficial effect on acrosomal retention of spermatozoa incubated at $37^{\circ} \mathrm{C}$ (Senger \& Saacke, 1973).

Saacke \& White (1972) have demonstrated that changes in the morphology of the acrosome of unfixed bovine spermatozoa can be critically monitored and quantitated using the differential interference-contrast microscope, and that acrosomal retention during incubation at $37^{\circ} \mathrm{C}$ has a positive correlation with field fertility (\%90-day non-return to service) in artificially inseminated dairy cattle. The present experiments were therefore designed to characterize further the influence of serum-induced agglutination on the structural integrity of bovine spermatozoa after conventional freezing and thawing for artificial insemination.

\section{Materials and Methods}

\section{Experiment I}

This experiment was designed to evaluate the effect of homologous serum on agglutination and maintenance of the acrosomal cap after thawing.

Semen was collected by artificial vagina from bulls housed at Select Sires, Inc., Plain City, Ohio. One ejaculate from each of 10 bulls was used in a split-ejaculate technique. Each ejaculate had a minimum of $50 \%$ motility and $900 \times 10^{6} \mathrm{spermatozoa} / \mathrm{ml}$ before dilution. For serum preparation,

\footnotetext{
* Present address: Department of Animal Sciences, Washington State University, Pullman, Washington 99163,
} U.S.A. 
blood was collected by jugular puncture from virgin heifers and allowed to coagulate for $1 \mathrm{hr}$ at room temperature $\left(20-22^{\circ} \mathrm{C}\right)$. The clots were separated from the serum by centrifugation $(12,100 \mathrm{~g}$ for $10 \mathrm{~min}$ ) and equivalent portions of serum from each of 10 animals were pooled. Serum was heated at $56^{\circ} \mathrm{C}$ for $1 \mathrm{hr}$, cooled, placed in plastic straws and stored in liquid nitrogen $\left(-196^{\circ} \mathrm{C}\right)$ until use.

Treatments were based upon a pilot study which showed that optimum benefits of serum were achieved by adding the serum with the glycerol fraction before freezing (Treatment 2 ) or after thawing (Treatment 1). Serum added before glycerolation resulted in sperm damage.

A final concentration of $10 \%(\mathrm{v} / \mathrm{v})$ serum in the semen diluents was used. The constituents of the semen diluents for giving $20 \%$ egg yolk and $7 \%$ glycerol before freezing were: Fraction A$20 \mathrm{ml}$ egg yolk and $80 \mathrm{ml} 2.9 \%(\mathrm{w} / \mathrm{v})$ sodium citrate dihydrate; Fraction B1-20 ml egg yolk, $14 \mathrm{ml}$ glycerol and $66 \mathrm{ml} \mathrm{2.9 \% (w/v)} \mathrm{sodium} \mathrm{citrate} \mathrm{dihydrate;} \mathrm{Fraction} \mathrm{B2-20} \mathrm{ml} \mathrm{egg} \mathrm{yolk,} 14 \mathrm{ml}$ glycerol, $46 \mathrm{ml} 2.9 \%$ sodium citrate dihydrate and $20 \mathrm{ml}$ homologous serum, and each fraction contained 500 units potassium penicillin $\mathrm{G} / \mathrm{ml} ; 50 \mu \mathrm{g}$ dihydrostreptomycin sulphate $/ \mathrm{ml}$ and $0 \cdot 1 \mathrm{mg} \alpha$-amylase $/ \mathrm{ml}$.

Except for the inclusion of serum in the diluent, preparation of semen for freezing was conventional. Ejaculates were initially diluted in a volume of $50 \mathrm{ml}$ with Fraction $\mathrm{A}$ and cooled to $5^{\circ} \mathrm{C}$ in $1 \mathrm{hr}$. The partly diluted semen was then further diluted to a concentration of $140 \times 10^{6} \mathrm{cells} / \mathrm{ml}$ using Fraction A which had been pre-cooled to $5^{\circ} \mathrm{C}$. An equal volume of the appropriate Fraction $B$ was then added in increments of $10,20,30$ and $40 \%$ by volume at 10-min intervals to give a final dilution of $70 \times 10^{6}$ cells $/ \mathrm{ml}$. The diluted semen was placed into $0.5 \mathrm{ml}$ plastic straws and allowed to equilibrate for $4 \mathrm{hr}$ before freezing in liquid nitrogen vapour at $-180^{\circ} \mathrm{C}$. After exposure to the vapour for $11 \mathrm{~min}$, the straws were plunged into liquid nitrogen and stored for approximately 4 weeks before evaluation.

For evaluation, semen was thawed by plunging 6 straws into a water bath at $50^{\circ} \mathrm{C}$ for $15 \mathrm{sec}$. The straws were thoroughly dried and the contents (approximately $3 \mathrm{ml}$ ) were pooled. For the control treatment and Treatment $2,2 \mathrm{ml}$ semen were transferred to a $10-\mathrm{ml}$ test tube for incubation. For Treatment $1,1.8 \mathrm{ml}$ semen was added to a tube containing $0.2 \mathrm{ml}$ serum and gently mixed. All samples were coded and incubated at $37^{\circ} \mathrm{C} \pm 0 \cdot 3^{\circ} \mathrm{C}$. Evaluation for the \% intact acrosomes and \% head-tohead agglutination was conducted before $(0 \mathrm{hr})$ and after incubation for 3,6 and $9 \mathrm{hr}$.

The integrity of the acrosome was determined by the presence of the apical ridge (Saacke \& Marshall, 1968) which was observed at a magnification of $\times 1250$ with a Zeiss differential interferencecontrast microscope (after Nomarski). Quantification of intact acrosomes was accomplished by random movement of the mechanical stage and counting 100 cells in each of two unfixed wet smears of the same sample. A discrepancy of more than $8 \%$ was checked by counting a third smear and averaging the closest pair of counts. The agglutination percentage was obtained from a differential count of agglutinated and single cells in microscopic fields obtained by a random movement of the mechanical stage. Two counts of 100 cells each were made immediately after the counts on the same smears for the \% intact acrosomes. All samples were coded and values recorded after completion of the counts.

\section{Experiment $I I$}

In Exp. I there was a positive correlation of acrosomal integrity and agglutination. Therefore, utilizing 8 (random) of the 10 ejaculates from Exp. I, Exp. II was designed to compare the ageing characteristics of the agglutinated cell population with that of the single cell population. To eliminate bias and adhere to the incubation schedule, each serum treatment was represented by two aliquots thawed independently; in one only agglutinated cells were counted for intact acrosomes, and in the other only single cells were counted for intact acrosomes. An aliquot consisted of semen from 5 straws thawed at $50^{\circ} \mathrm{C}$ for $15 \mathrm{sec}$, pooled and standardized for volume at $2 \mathrm{ml}$. Evaluations for $\%$ intact acrosomes and \% agglutination were made after $0,3,6$ and $9 \mathrm{hr}$ of incubation at $37^{\circ} \mathrm{C}$.

\section{Preparation of spermatozoa for ultrastructural observation}

Ultrastructural studies were undertaken to evaluate the nature of the association between agglutinated spermatozoa. Also of interest were possible ageing changes in the acrosomes of agglutinated 
cells (after $9 \mathrm{hr}$ of incubation) that could not be observed or predicted from differential interferencecontrast microscopy.

Ten straws of frozen semen from 1 ejaculate diluted in egg yolk-citrate-glycerol were thawed. The contents were pooled, diluted to $10 \%$ by volume with cow serum heated at $56^{\circ} \mathrm{C}$ for $1 \mathrm{hr}$, and immediately placed in a water bath at $37^{\circ} \mathrm{C}$. Fixation at 0 and $9 \mathrm{hr}$ was accomplished by adding $3 \mathrm{ml} \mathrm{6 \%}$ glutaraldehyde, buffered to $\mathrm{pH} 7 \cdot 2-7 \cdot 4$ with $0 \cdot 1 \mathrm{M}$-phosphate buffer to each $3 \mathrm{ml}$ semen. The fixative was warmed to $37^{\circ} \mathrm{C}$ before use to avoid possible damage to membranes as a result of 'cold shock'. After fixation for $30 \mathrm{~min}$, samples were centrifuged at $750 \mathrm{~g}$ for $5 \mathrm{~min}$. The pelleted spermatozoa were transferred to a Petri dish containing semi-solid $1 \%$ purified agar (Blom \& Birch-Anderson, 1961). After solidification at room temperature, agar cubes (2-3 $\left.\mathrm{mm}^{3}\right)$ containing the spermatozoa were washed in $0 \cdot 1 \mathrm{M}$-phosphate buffer and dehydrated in a graded ethanol series. The agar was trimmed from the sperm pellets which were embedded in Epon 812. Light gold sections were cut with a diamond knife on a Porter-Blum MT-2 Ultramicrotome and stained in saturated uranyl acetate (Venable \& Coggeshall, 1965).

\section{Results}

\section{Experiment $I$}

Analysis of variance showed a significant $(P<0.01)$ difference in the $\%$ intact acrosomes in the two treatment groups compared with the control spermatozoa up to $6 \mathrm{hr}$ after thawing. By $9 \mathrm{hr}$ these differences had disappeared (Table 1). No significant differences in $\%$ head-to-head agglutination were found, but there was a significant $(P<0.01)$ decline during incubation (Table 1$)$. Considering all observations, a correlation coefficient $(r)$ of $0.49(P<0.01)$ was present between the \% intact acrosomes and \% agglutination.

Table 1. The results of Exp. I showing the means (of 10 ejaculates) for the $\%$ intact acrosomes and $\%$ head-to-head agglutination of bovine spermatozoa incubated after treatment with serum before freezing or after thawing

\begin{tabular}{|c|c|c|c|c|c|c|c|c|}
\hline \multirow{3}{*}{$\begin{array}{c}\text { Serum } \\
\text { treatment }\end{array}$} & \multicolumn{4}{|c|}{$\%$ Intact acrosomes $*$} & \multicolumn{4}{|c|}{$\%$ Agglutination $\dagger$} \\
\hline & \multicolumn{4}{|c|}{ Incubation time (hr) } & \multicolumn{4}{|c|}{ Incubation time (hr) } \\
\hline & 0 & 3 & 6 & 9 & 0 & 3 & 6 & 9 \\
\hline None (controls) & $76 \cdot 1^{a}$ & $65 \cdot 1^{a}$ & $60 \cdot 4^{a}$ & $56 \cdot 7^{\mathrm{a}}$ & 0 & 0 & 0 & $\mathbf{0}$ \\
\hline After thawing & $82 \cdot 7^{b}$ & $69 \cdot 9^{b}$ & $65 \cdot 7^{b}$ & $61 \cdot 0^{a}$ & $53 \cdot 1^{a}$ & $51 \cdot 2^{a}$ & $44 \cdot 7^{b}$ & $45 \cdot 8^{b}$ \\
\hline Before freezing & $88 \cdot 3^{c}$ & $75 \cdot 9^{c}$ & $66 \cdot 1^{b}$ & $57 \cdot 5^{\mathrm{a}}$ & $53 \cdot 8^{a}$ & $50 \cdot 2^{a}$ & $41 \cdot 1^{b}$ & $38 \cdot 1^{b}$ \\
\hline
\end{tabular}

* Different superscripts in each column designate significant differences $(P<0.05)$ as tested by Duncan's Multiple Range Test.

$\dagger$ Different superscripts in each row designate significant differences $(P<0.05)$ as tested by Duncan's Multiple Range Test.

\section{Experiment II}

According to the analyses of variance, a significant $(P<0.01)$ proportion of the variation in $\%$ intact acrosomes was due to treatment and the population of cells counted, i.e. single versus agglutinated cells (Table 2). The \% intact acrosomes within the agglutinated cell populations were quite high throughout and did not differ in the two serum treatments. The single-cell populations were significantly different among treatments $(P<0.05)$; in Treatment 2 there were more cells with intact acrosomes than in Treatment 1 and acrosomal deterioration was more rapid in the treated than in the control spermatozoa. The agglutinated cells from both serum treatments were superior to the controls with respect to acrosomal maintenance $(P<0.01)$, but agglutination declined with incubation (Table 3). The more rapidly deteriorating single cells of serum-treated samples were therefore probably composed of those which did not agglutinate and those leaving the agglutinated groups during incubation. 
Table 2. The \% intact acrosomes of agglutinated and single cells after incubation at $37^{\circ} \mathrm{C}$ of bovine spermatozoa (mean of 8 ejaculates) treated with serum before freezing or after thawing

\begin{tabular}{lcccc}
\hline & \multicolumn{4}{c}{ Incubation time (hr) } \\
\cline { 2 - 5 } Serum treatment & 0 & 3 & 6 & 9 \\
\hline None (controls) & $82 \cdot 0^{\mathrm{d}}$ & $70 \cdot 4^{\mathrm{d}}$ & $63 \cdot 7^{\mathrm{d}}$ & $52 \cdot 1^{\mathrm{d}}$ \\
$\begin{array}{l}\text { After thawing } \\
\quad \text { Agglutinated cells }\end{array}$ & $95 \cdot 1^{\mathrm{a}}$ & $90 \cdot 1^{\mathrm{a}}$ & $86 \cdot 7^{\mathrm{a}}$ & $84 \cdot 6^{\mathrm{a}}$ \\
$\quad$ Single cells & $73 \cdot 0^{\mathrm{c}}$ & $57 \cdot 2^{\mathrm{b}}$ & $40 \cdot 7^{\mathrm{b}}$ & $26 \cdot 4^{\mathrm{b}}$ \\
Before freezing & $95 \cdot 7^{\mathrm{a}}$ & $92 \cdot 6^{\mathrm{a}}$ & $90 \cdot 6^{\mathrm{a}}$ & $88 \cdot 3^{\mathrm{a}}$ \\
$\quad$ Agglutinated cells & $90 \cdot 1^{\mathrm{b}}$ & $61 \cdot 9^{\mathrm{b}}$ & $49 \cdot 9^{\mathrm{c}}$ & $34 \cdot 5^{\mathrm{c}}$ \\
$\quad$ Single cells & &
\end{tabular}

Different superscripts in each column designate significant differences $(P<0.05)$ as tested by Duncan's Multiple Range Test.

Table 3. The \% head-to-head agglutination (means \pm S.D.) of bovine spermatozoa ( 8 ejaculates) treated with serum before freezing and after thawing and incubated at $37^{\circ} \mathrm{C}$

\begin{tabular}{lcccc}
\hline \multirow{2}{*}{$\begin{array}{c}\text { Serum } \\
\text { treatment }\end{array}$} & 0 & 3 & 6 & 9 \\
\cline { 2 - 5 } & $60 \cdot 5^{\mathrm{a}} \pm 14 \cdot 3$ & $55 \cdot 7^{\mathrm{b}} \pm 13 \cdot 8$ & $52 \cdot 9^{\mathrm{b}} \pm 12 \cdot 7$ & $49 \cdot 7^{\mathrm{c}} \pm 11 \cdot 9$ \\
After thawing & $64 \cdot 9^{\mathrm{a}} \pm 12 \cdot 7$ & $55 \cdot 1^{\mathrm{b}} \pm 13 \cdot 5$ & $47 \cdot 1^{\mathrm{c}} \pm 12 \cdot 3$ & $44 \cdot 4^{\mathrm{c}} \pm 10 \cdot 3$ \\
\hline
\end{tabular}

Different superscripts in rows designate significant $(P<0 \cdot 01)$ differences as tested by Duncan's Multiple Range Test.

Motility in the serum-treated samples could not be estimated accurately because of the agglutination. However, all motility had ceased by $6 \mathrm{hr}$ in the control samples and the single cells of serumtreated samples, while weak but distinct flagellar motion was still evident in agglutinated cells at $9 \mathrm{hr}$.

\section{Morphological observations}

The numbers of agglutinated spermatozoa ranged from 2 to 10 cells/group. Most often the heads were orientated in the same direction and were characterized by the presence of an apical ridge (Pl. 1, Fig. 1). Judged by the appearance of the apical ridge, there was little evidence of ageing of agglutinated as compared to single cells in the same sample. However, agglutination declines with incubation, suggesting that ageing of agglutinated cells does occur. Nevertheless, the association and structural integrity of agglutinated cells initially $(0 \mathrm{hr})$ and after $9 \mathrm{hr}$ of incubation were ultrastructurally the same.

Ultrastructural observations of 50 agglutinated groups showed that the cell membranes of adjacent cells were in close apposition in the acrosomal region only (PI. 2, Figs 2 and 3). There was moderate electron density between adjacent membranes at their closest association but fusion was not observed.

\section{Discussion}

Chang (1947) first suggested that serum-induced head-to-head agglutination of spermatozoa did not involve dead or immotile cells. The current study shows that the process is a selective one in that cells with intact acrosomal and cell membranes are the most likely to agglutinate. Head-to-head agglutination may depend solely upon the integrity of these membranes, since (i) the relatively few agglutinated cells without intact membranes (Table 2) may have been simply entrapped in the agglutinated groups or in the process of ageing and dissociation from the agglutinated groups, and (ii) acrosomal integrity of agglutinated cells did not significantly decline over the $9 \mathrm{hr}$ incubation (Table 2). Obviously, acrosomal and/or cell membrane integrity may not be the only prerequisite 
PLATE I

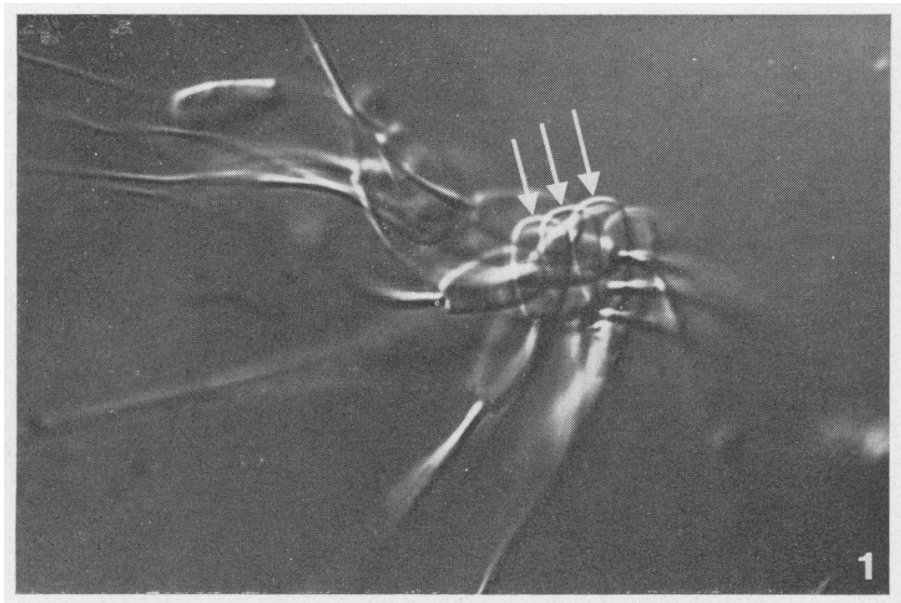

Fig. 1. A differential incererence-contrast nucrograph illustrating head-lo-inead agglutination of bull spermatoroa treited with serum. Agglutinated cells were characterized hy the presence of an apical ridge (arroms) $\times 3.5000$. 


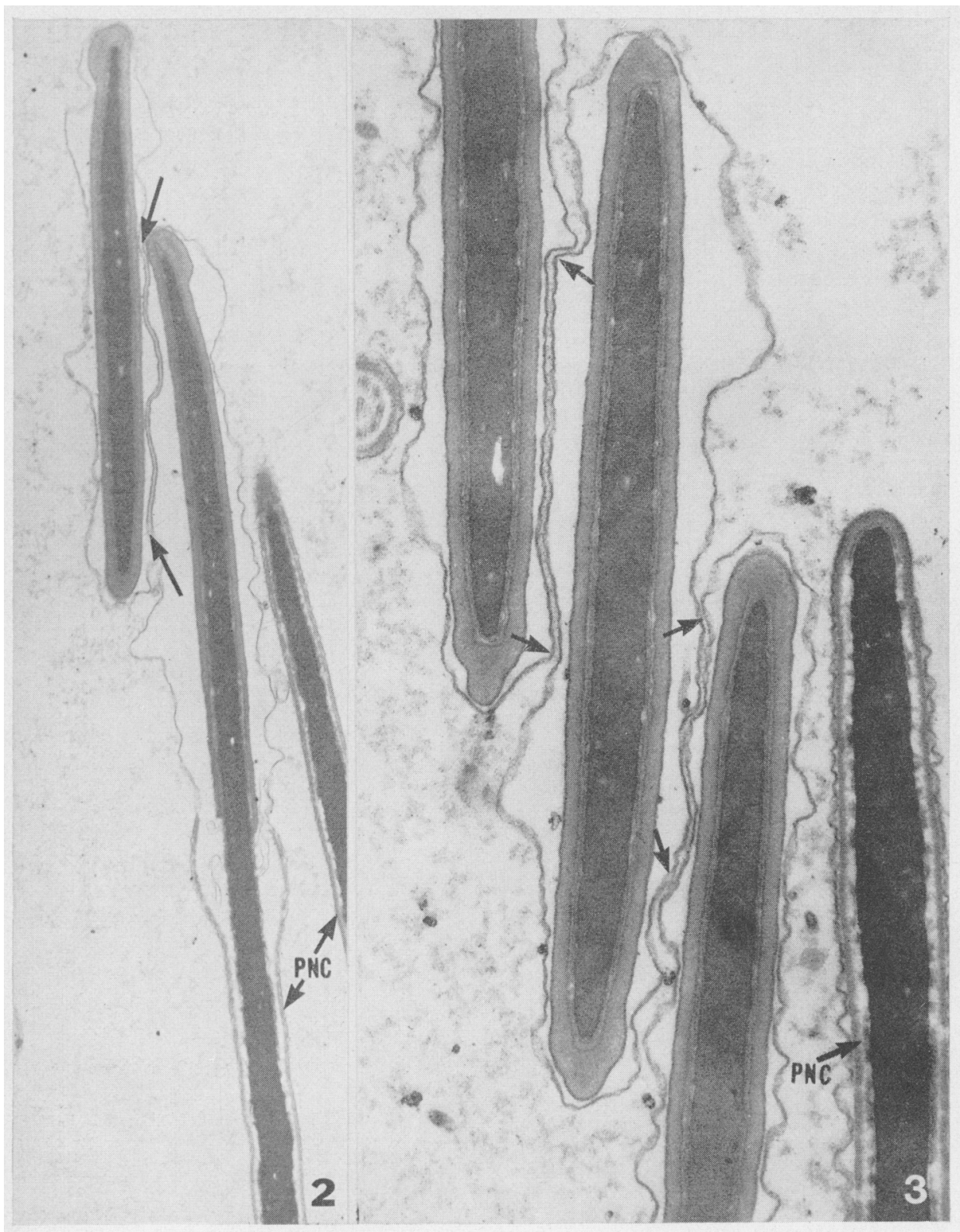

Fig. 2. A lower power electron micrograph of two bull spermatozoa agglutinated head-to-head. The cell membranes (between arrows) are closely associated in the acrosomal region only where they follow a common contour. There is no membrane fusion. The cell membrane, covering the post-nuclear cap region (PNC) of adjacent cells are not closely associated, and are not associated with the membrane of the acrosomal region of adjacent cells. $\times 14,600$.

Fig. 3. An electron micrograph of three spermatozoa agglutinated head-to-head. The cell membranes are closely associated but are not fused in restricted regions (between arrows). The cell membrane covering an adjacent cell sectioned in the post-nuclear cap region (PNC) is not involved with the membranes of the acrosomal region. $\times 24,800$. 
for agglutination since intact motile spermatozoa were also present in the single cell population of serum-agglutinated samples. However, the more rapid loss of the acrosome in these cells compared to that in the control samples (Table 2) suggests that changes undetectable by conventional microscopy occur and are quickly followed by structural deterioration. Such ageing- or injury-related alterations may involve changes in the surface chemistry and/or electrical potential of the cell.

Serum-induced head-to-head agglutination does not appear to be entirely antibody-dependent (Boettcher, Kay, Rumke \& Wright, 1971). It also occurs in normal sera (Chang, 1947; Padma, 1972a) and with sera from related species (Padma, 1972b). Padma (1972a) has identified the agglutinin as a natural antibody in the IgG fraction of normal rabbit sera, while Boettcher et al. (1971) have found sperm agglutinins in the $\beta$-globulin fraction of normal sera. The present data show that the agglutinin is not deleterious to the structural integrity of bovine spermatozoa.

Head-to-head agglutination of spermatozoa has been observed to occur naturally (Bedford, 1970), and has been induced by washing cells (Dott \& Walton, 1960) as well as by exposing them to divalent cations (Bedford, 1970) and fluids of the female genital tract (Olds \& VanDemark, 1957; Lindahl, 1966). Lindahl (1973) has shown that spontaneous head-to-head agglutination is ATPdependent and is counteracted in the bull by a seminal anti-agglutinin of prostatic origin (Lindahl \& Kihlstrom, 1954).

Considering the selective nature of serum-induced head-to-head agglutination and its relation to acrosomal alteration, two avenues of future research are indicated: to define (1) the role of agglutination in fertility with attention given to capacitation, selective sperm transport and sperm phagocytosis by uterine leucocytes, and (2) the relationship of agglutination to semen quality, since dead, injured or aged cells resist this type of agglutination.

We thank Mrs Margaret Ristroph and Mrs Betsey Golon for their excellent technical assistance. This work was supported by Curtiss Breeding Service, Division of Searle Agriculture, Inc. and the William M. Hackman Foundation.

\section{References}

Barros, C., Arrau, J. \& Herrera, E. (1971) Induction of the acrosome reaction of golden hamster spermatozoa with blood serum collected at different stages of the oestrous cycle. J. Reprod. Fert. 28, 67-71.

BfDFoRd, J.M. (1970) Observations on some properties of a potent sperm-head agglutinin in the semen of a fertile rabbit. $J$. Reprod. Fert. 22, 193-198.

Blom, E. \& Birch-Anderson, A. (1961) An "apical body" in the gales capitus of the normal bull sperm. Nature, Lond. 190, 1127-1128.

Boettcher, B., Kay, D.J., Rumke, P. \& Wright, L.E. (1971) Human sera containing immunoglobulin and non-immunoglobulin spermagglutinins, Biol. Reprod. 5, 236-245.

Chang, M.C. (1947) The effects of serum on spermatozoa. J. gen. Physiol. 30, 321-335.

DotT, H.M. \& Walton, A. (1960) Effects of dilution and washing on ram spermatozoa studied by the technique of flow dialysis. J. Reprod. Fert. 1, 350-354.

EDWARDS, R.G. (1960) Complement-fixing activity of normal rabbit serum with rabbit spermatozoa and seminal plasma. J. Reprod. Fert. 1, 268-282.

LINDAHL, P.E. (1966) Sperm agglutinating and antiagglutinating factors in normal follicular fluid from cattle. Int. J. Fert. 11, 297-305.

LINDAHL, P.E. (1973) Activators of the ATP-dependent surface reaction in the apical cell membrane of the bull-sperm head, causing head to head association. Expl Cell Res. 81, 413-431.

Lindahl, P.E. \& Kinlstrom, J.E. (1954) An antiagglutinic factor in mammalian sperm plasma. Fert. Steril. 5, 241-255.

Olds, D. \& VanDemark, N.L. (1957) The behavior of spermatozoa in luminal fluids of bovine female genitalia. Am. J. vet. Res. 18, 603-607.

Padma, M.C. (1972a) Nature of the spermagglutinin in the normal serum of rabbits. Nature, Lond. 238, 25-26.

Padma, M.C. (1972b) Presence of a sperm agglutinating factor in the normal serum of rabbits against homologous spermatozoa. J. Reprod. Fert. 31, 119122.

SAACKe, R.G. \& MARShall, C.E. (1968) Observations on the acrosomal cap of fixed and unfixed spermatozoa. J. Reprod. Fert, 17, 511-514.

SAACKe, R.G. \& White, J.M. (1972) Semen quality tests and their relationship to fertility. Proc. 4th Tech. Conf., Anim. Reprod. and A.I. Chicago, pp. 22-27.

SEnGER, P.L. \& SAACKe, R.G. (1973) Effects of blood serum on bovine spermatozoa. J. Anim. Sci. 37, 328, Abstr.

Venable, J.H. \& Coggeshall, R. (1965) A simplified lead citrate stain for use in electron microscopy. J. Cell Biol. 25, 407. 